\title{
Japanese university students' longing for an idealized France and encounters with global English in Europe
}

\author{
Yoko Kobayashi $^{1}$ (i)
}

Accepted: 27 October 2021 / Published online: 20 November 2021

(c) The Author(s), under exclusive licence to Springer Nature B.V. 2021

\begin{abstract}
Japanese college students' akogare (meaning "longing") for an idealized West has conventionally been researched and discussed under the assumption that the West is synonymous with Anglophone countries and that an encounter with the West is categorically an international experience. The present study provides new insights by exploring Japanese college students' longing for an idealized France through a content analysis of blogs and reflective entries written by students during or after participating in a French study abroad program. The analysis reveals that Japanese students from prestigious universities display a high level of satisfaction irrespective of how well they are able to use French. This finding, which is intertwined with the nature of fun-oriented study abroad programs, is also related to the widespread use of English in Europe. The linguistic discovery reminds students of the overriding global status of English vis-à-vis French as a regional language. The study provides future research directions and pedagogical implication in light of (1) increasingly fierce competition for the securement of language course takers, which drives the institutional reproduction of language ideologies and the implementation of fun study abroad programs, and (2) the long-term effectiveness of such ideology-driven survival strategies amid the changing popularity of foreign languages in Japan and elsewhere.
\end{abstract}

Keywords Higher education in Japan · French study abroad programs - An idealized West · Language ideologies

\section{Introduction}

The ideology of English language study in Japan aligns the use of English with a sense of being international and a longing for an idealized West. A Japanese professor who teaches at both 4- and 2-year Christian women's colleges observed that many of his students choose the college staffed with "white' ministers and professors" "because it symbolizes the "white West"" and enrolling in English courses taught by Western native English speakers "helps them to feel international" [emphasis in original] (Nonaka, 2018: 100). An

Yoko Kobayashi

yokobaya@iwate-u.ac.jp

1 Faculty of Humanities \& Social Sciences, Iwate University, 3-18-8 Ueda, Morioka, Iwate 020-8550, Japan 
American instructor who teaches English literature at a Japanese university where eikaiwa (meaning "English conversation") is considerably more popular than literature lamented that he and his colleagues were positioned to "act as decoration, or tokens that make an English or foreign or global studies department look "international"” (Chilton, 2016: 108).

In Japan, discussion and research on English ideology regularly overlook the teaching of languages other than English. This tendency reflects the limitations of the existing literature, which either rests on or critiques the assumption that English is the gateway to the world, both within the domain of English teaching and learning. The present study expands our understanding of the ideology of English language learning by shedding light on Japanese college students' longing for France and their participation into French study abroad programs, from a viewpoint that the existent literature knowledge base is confined by the equation of the West with Anglophone countries.

Locally published studies on Japanese college students' enrollment in French language courses indicate that the key motivation for participating in French study abroad programs is a sense of longing for France. Mogi (2016) conducted a questionnaire survey and an interview study with 27 (all female) students who participated in a month-long study abroad program in France organized by his affiliation, a French Studies department at a private Catholic university. He contends that "most of the students take part in the program out of their akogare for French lifestyle and culture rather to achieve career success" (pp. 68-69; translated into English by the author). Ishimaru (2009) also reports a compatible finding. A questionnaire survey conducted with 138 Japanese college students majoring in French (104 women; 34 men) and 44 non-majors (32 women; 10 men) revealed that the word "France" invokes "overwhelmingly" positive images among both groups and that their decision to enroll in French was motivated by their "akogare" for France, French architecture (e.g., Eiffel Tower and the Palace of Versailles), and French sophisticated culture (e.g., Paris Fashion Week and luxury brands) (pp. 137-138).

So far, existing research has not clarified how French and France are conceived of in the minds of Japanese college students who have been exposed to dominant representations of English language study as a conduit to the West and international experiences. The present study explores this theme through a content analysis of the blogs of Japanese college students studying abroad in France and students' testimonials that have been posted on the websites of language departments and language programs.

\section{Contextual background}

\section{The changing role of Western languages in Japan}

During the Meiji Period (1868-1912), Japan underwent a drastic transformation from the feudal system to the rule by the new Meiji Government. Scholars have attributed this transformation to "the rapid acquisition of Western knowledge and skills" through the "employment of foreign nationals and dispatch of students for overseas study" (JICA Research Institute, 2004: 15-16) (see also Monbusho, 1980). The Meiji government's absorption of skills and knowledge from the USA, England, France, and Germany also influenced the modernization of Japan's education system. Tokyo Kaisei Gakko, which became the University of Tokyo, and other institutions of higher education employed American, British, French, and German professors of law and scientific disciplines such as engineering, medicine, and astronomy (Monbusho, 1980). In addition, English, 
French, and German were taught "for the very practical purpose of facilitating the gaining of knowledge from western countries" (Gottlieb, 2012: 81).

During the postwar period when Japan was occupied by the USA, the country again underwent a historical transformation from an imperial military state to a democratic one. As a result of higher education reforms during the occupation of Japan (1945-1952), 69 new system national universities were established (Monbukagakusho, 1990), foreign language study was designated as a supplementary subject (Fan, 2019), and the study of English was prioritized over other foreign languages, namely French and German (Gottlieb, 2012: 83).

Until 1991, Japanese university students were required to complete an English course as well as an additional foreign language course for university graduation. However, in 1991, the Standards for the Establishment of Universities was amended, which empowered each institutions of higher education to devise their own curriculums (Monbukagakusho, 1996). This resulted in the removal of the second foreign language study as a graduation requirement at many private universities (Gottlieb, 2012: 83; Kobayashi, 2013). Thus, until in the early 1990s, foreign languages courses could rely on a large and stable number of students required to take their classes, which amounted to the normalcy of large-sized classes and the steady employment of tenured Japanese instructors of German and French. In particular, from the postwar Japan to the economic growth period (from 1945 to 1969), France and the French language re-emerged as the beacon of Japanese people's "dream and akogare," a longing that was amplified by "Japanese citizens' cultural appetite" (Tajima, 2002: 18).

The fever of intellectual curiosity for Western high culture started to wither as Japan's so-called economic miracle led to the rise of a new Japanese middle-class and a steep rise in university admissions to newly established private universities, which are often dubbed as a "leisure land" where students spend more time on social activities such as partying, participating in club activities, and working parttime jobs than on their academic studies (Nagatomo, 2012; Doyon, 2001; Kobayashi, 2018, 2021). Seemingly, the foundation of Western language departments teaching Western languages and cultures at co-ed and women's colleges contributed to high university enrollment among middle-class students who harbored a sense of longing for the West. However, their West-centric longing no longer signified an intellectual desire to become proficient in a foreign language and appreciate Western knowledge. The decrease in postwar "Japanese citizens' cultural appetite" for French high culture (Tajima, 2002: 18) is reflected on the website of a French (and Italian) Language Program at one of Japan's top-tier universities. The website highlights the most fun parts of its study abroad program in France, including "trips to Loire Valley castles and Monet's home in Giverny, interactions with host families, and the opportunity to taste apricot jam made from fruits grown in a garden as well as authentic crepes, cheeses, and croissants" [translated into English by the author] (College of Arts and Sciences of the University of Tokyo, 2019).

Programs and departments teaching once well-respected European languages are now challenged by a powerful English ideology that naturalizes encounters with the Anglophone West as international and cross-cultural learning. This ideology is detrimental to the promotion of languages other than English. The following subsection briefly describes a popular TV commercial of a major English language school in Japan that has been broadcast nationwide for 6 years. This popular advertising demonstrates the dominant English ideology pervasive in Japan. 


\section{Equating contact with the Anglophone West with an international experience}

From 2013 to December 2019, a major English language school in Japan aired a series of TV commercials nationwide that featured Ishihara Satomi, a local female celebrity. In the commercial, she is shown visiting iconic Anglophone cities on a solo vacation. Each commercial starts with the English name of the featured city and a famous landmark, followed by scenes of Ishihara happily engaging in conversation with local English speakers. All the "locals" Ishihara converses with are exclusively white people who teach her about Western lifestyles. She meets a couple who practices what Ishihara calls "slow life" on Salt Spring Island (e.g., taking a walk in the forest and making trifle with locally grown raspberries), an elderly man on his way home from the grocery store to make a special dinner for his wife's "big five oh" birthday party, and more than 10 couples who attend a beautiful, spacious garden party at an upscale residence in Sydney. The only non-Western locals shown throughout the whole series are an elderly black taxi driver who helps her load her heavy luggage and a young black man who gives her directions. Most importantly, "ethnic" images have been categorically deleted from the scenes of these multicultural cities. Indeed, there are no Asian pedestrians, shots of Chinatown, or multilingual street signs.

All the Anglophone cities chosen for the settings of the commercials symbolize a foreign world outside of Japan where Ishihara happily engages in an international experience, despite all of the people she comes into contact with belonging to an idealized West. For example, near the end of a commercial shot in Sydney, Ishihara addresses the TV audience and announces in a joyous, loud voice in Japanese: "Thanks to my English speaking ability, I have been able to experience a wide range of wonderful encounters that I never could have imagined!" (translated into English by the author). Ishihara stands amidst more than 10 smiling and waving white couples and guests at an upscale garden party. The commercial ends by showing the following Japanese message on the screen: "Let's become happy with English." In another episode, Ishihara states in Japanese that "Speaking English and having direct contact with a country's way of life and culture is more fun than anything else." In an interview posted on the company's website, Ishihara claims that her improved English skills dispelled her anxiety about traveling abroad. Below is the first part of the Japanese language interview uploaded on Satomi's Lesson Report (January 2019), where she reflects on her 6-year-long experience of taking private English lessons at one of the school branches in Tokyo:

To be honest, I cannot recall how I felt six years ago, but one thing I know for sure is that I'm no longer afraid to go abroad and can have a normal, fun dinner with friends. All in all, what has changed the most is that I can spend my days more happily than six years ago and I am happy wherever I go. That is what I feel.

This series of commercials were so well- received that Ishihara came to be recognized as a bilingual, globe-trotting celebrity. According to a survey conducted in 2018 by a major provider of information and statistics on the Japanese entertainment business (Oricon Inc., 2018), Ishihara was ranked first as a celebrity among a list of celebrities from whom survey respondents would want to learn English from.

\section{Rationale and focus of the study}

Higher education institutions around the world must compete for prospective applicants, and they strategically use their websites to brand themselves as global institutions that can offer an abundance of international experiences (Fairclough, 1993; Lewin-Jones, 2019; 
Zhang \& O'Halloran, 2013). Study abroad programs are prominently highlighted in universities' promotional materials, including websites (Michelson \& Valencia, 2016). Advertising utilizes both textual and visual messages, with the latter functioning as an extension of the former (Kress \& van Leeuwen, 1996). Study abroad promotional materials idealize the host country, and depictions of a world of "fantasy" are "intensified by the promise of happiness and well-being through the students' smiling faces" (Michelson \& Valencia, 2016: 242).

On the one hand, the smiling faces of study abroad participants and their written testimonials serve the interests of institutions striving to attract prospective applicants. On the other hand, such texts and images cannot be dismissed as fabrications of the participants' satisfaction produced by the institution. Rather, by studying abroad and agreeing to have their pictures and testimonials featured on an institution's website, participants are implicated in reproducing and sustaining the dominant ideology that popularizes study abroad as opportunities to discover (idealized) worlds, engage in cross-cultural communication (with a specific type of local), and develop into (rhetorically) global citizens.

For example, Kinginger (2004) points out that culturally romanticized images of France pervasive in the USA impinge on college students' interest in studying French in the USA or in France, as demonstrated by the attitude of her student, Alice:

Alice's image of France recalls the many stereotypes of the French landscape within American cultural productions, [...]. When Bart Simpson (of the popular animated television series The Simpsons) goes to France as an exchange student, for example, he finds a landscape entirely composed of Impressionist paintings. In this version of France there is of course no misery: no slums, no poverty, no anonymous lowincome housing projects. Above all, there are no trailer parks. (p. 227)

Thus, visual and textual messages presented on institutions' websites are a form of social practice in that those ideological messages are embedded in broader social contexts that are determined by dominant ideologies and help maintain power relationships (Fairclough, 2013; van Dijk, 1993). The popularity of France and French among higher education institutions and study abroad program participants is attributable to the essentialized ideology that evokes romanticized image of the country and fuels prospective study abroad students' longing for the country. Given the sheer dominance of English ideology, which equates English-related activities in the Anglophone West with internationalization and global citizenship, it is necessary to examine college students' participation in studyin-France programs in the context of the intersection of globalized English ideology and idealized images of France.

\section{Methods}

\section{Data}

The study analyzes blog posts and personal testimonials written by Japanese college students during or after participating in short-term French study abroad programs. These blog posts and testimonials have been posted on the official websites of their language programs that organize and oversee study abroad programs. A search identified two prestigious national universities that uploaded detailed blogs and reports composed by French study abroad program participants: the above-mentioned French (and Italian) bukai [division] of 
College of Arts and Sciences of the University of Tokyo (http://langue-fr.c.u-tokyo.ac.jp) and the French shoubukai [small division] of Nagoya University (http://french.ilas.nagoyau.ac.jp/).

Writings by Nagoya University students were written as post-sojourn course assignments. From March 1 to 14 in 2015, 19 students participated in a study abroad program in Strasbourg and later submitted a report documenting three things that they had learned (2,000 words in Japanese) as well as something that surprised them (300 words in French) while in Strasbourg. Besides two reports, all of the students' Japanese language reports were uploaded to the French language division's website. The names of participants suggest an even distribution of both men and women. None of the participants had non-Japanese names. The testimonials from 2015 mark the second year of Nagoya University's French study abroad program, which was launched in 2014. Five out of 15 participants wrote and uploaded their taikenki (meaning "experience note") without any imposed writing format. Except in the first and second study abroad program held in 2014 and 2015, respectively, no other information about the current status of the program is available on the website.

Blogs written by the University of Tokyo students served as the primary data for this study. These blog posts describe in detail the everyday activities of students and were posed six times (every February from 2017 to 2020, once in September 2018, and once in September 2019). Approximately 10 to 12 study abroad participants in France (and Brussels in February 2018) took turns writing and posting daily journal entries during their 10 to 12 day-long trips. The journal entries did not have to conform to any set restrictions of format, and they covered the entire duration of the students' trips. The program provided opportunities for the participants to participate in both group and individual activities such as guided tours, interactions with local Japanese language students, and homestays. The names and pictures of the participants suggest that there was a relatively even mix of men and women, all of whom had Japanese names. The participants were composed of firstyear students enrolled in a beginner-level French class with a small-class size that was designed for intensive learning. The course was open to students of both the human and natural sciences.

\section{Analysis}

The present study employs inductive content analysis in order to categorize informants' words and writings into themes for the purpose of "making replicable and valid inferences from texts (or other meaningful matter) to the contexts of their use" [emphasis in original] (Krippendorff, 2004: 18). More specifically, this qualitative analysis of manifest content seeks to better understand the significance of the French language for Japanese college students by categorizing their words and writings into relevant themes that reflect a shared meaning.

The contents of University of Tokyo students' blogs can be categorized into the following two major themes: (1) expected or unexpected experiences and (2) motivation to study French in Japan or in France. The experiences were further classified into either positive incidents/activities or negative ones in reference to Japanese expressions used to indicate emotions (e.g., tanoshikatta [had fun], ureshikatta [was happy], omoshirokatta [was interesting], fuanninarimashita [got worried]). Moreover, all the expected or unexpected incidents or activities were examined in terms of references to language learning and use 
(e.g., French, Japanese) and how such references are linked to students' motivation to study French and willingness to use French in France. The reports and testimonials of Nagoya University students were used for data triangulation to corroborate the credibility of the categorizations (Patton, 2002).

\section{Findings}

\section{Expected fun encounters with an idealized France}

In their blogs, students from the University of Tokyo report overwhelmingly fond experiences, irrespective of types of activities and whether those experiences were expected or unexpected. Most student testimonials incorporate Japanese expressions of happiness, pleasure, satisfaction, fulfillment, and so on. Blogs are commonly accompanied by photos that capture elements of local life, such as pictures of local students majoring in Japanese and pictures of food taken at restaurants. Elements of authentic French life judged to be in conflict with an idealized France, such as non-white immigrants, are kept out of sight and made invisible to the participants. Only one Nagoya University student took notice of "the omnipresence of beggars sitting on the street and asking for money from pedestrians" in Strasbourg in 2015. In other words, similar to the TV image of Ishihara as a happy holidaymaker encountering an idealized West, Japanese participants in short-term French study abroad programs are granted privileged access to an idealized France via visits to the art museums they have dreamed of, opportunities to taste authentic foods and desserts, and group explorations of the city, safely chaperoned by a Japanese or local professor or local students.

Students who enroll in short-term study abroad programs are not necessarily driven by a long-term commitment to studying the language and culture of the target country. Therefore, such participants receive a sense of satisfaction and accomplishment within days after arrival. For example, on the ninth day of the program, a student from the University of Tokyo ended her journal entry on February 12, 2019, with a list of three goals she had accomplished: (1) to get a real sense for living in France by walking around the cities [Paris and Lyon], (2) to learn what French people of her generation are thinking by making friends with them, and (3) to enjoy non-Japonized, authentic French dishes. Her conviction that she "was able to fulfill all of these wishes of mine" after spending just 9 days in the country is analogous to Ishihara's experience in Anglophone cities shown on TV and vacationers who indulge in fun activities.

Moreover, Japanese university students' experiences of struggling to speak and understand French did not negatively affect their emotional states, as evidenced by the upbeat and jovial tone of their writing when discussing language problems (e.g., ending a passage with the Chinese character for laughter, which is the Japanese version of LOL). This is not only due to the nature of "short-term 'vacation study abroad' in which travel is more closely associated with leisure and entertainment than effort and focused learning" (Kinginger, 2009: 11) but also because of the wide-spread use of English in Europe.

\section{Unexpected encounters with global English in France}

Japanese college students who study in France discover that English is widely used in France, both at local host institutions and in public places. One student from Nagoya 
University discussed at length the widespread use of English in France as one of his three surprising experiences:

The second thing that I learned in France is that being able to speak English is of help after all. [....] Before leaving for France, I assumed that I wouldn't use English much there [in Strasbourg], except when using public transit, such as at airports and train stations. However, I discovered that there are many situations where English can come in handy, to the point where I realized that one can communicate with locals to some extent even if one cannot speak French. What I learned from this French study abroad program is how much of an advantage one can gain abroad by being proficient in English, regardless of whether one is in an English-speaking country or not. [....] (Translated into English by the author)

Another Nagoya University student recalled unexpected encounters with French people who were willing to use English when speaking with foreign visitors:

One thing that surprised me in France is the fact that French people speak English without hesitation. Prior to my participation in this program, I held the very rude, stereotypical assumption that French people disregarded English and demanded to speak in French regardless of the circumstance. But I learned in France that this was not the case at all and that they proactively switched to English when I was trying to make myself understood using my poor French. In particular, I was very surprised to be spoken to in English by a senior couple when I visited them during a home visit.

The University of Tokyo students also came into contact with English-speaking locals and were impressed by the abundance of English menus and signs (e.g., at the Council of Europe Headquarters). However, none of the students commented on the fact that their study abroad programs were held in cities thronged with foreign students and tourists and the possibility that English-language services might not be widely available in rural areas.

\section{Motivation to study French in Japan or in France}

A total of 10 students described their decision to study French in Japan or in France. The motives contained in the translated transcripts below have been divided into two categories. The first category contains family-related motives, which were mentioned by three students who have had personal contact with France or French people:

1. One of the reasons I chose to study French is because I lived in France when I was an elementary school student (U of T student, February 2017).

2. I used to live in Brussels but wasn't able to become proficient in French. I chose French as a second foreign language because I dream of living in the city while using French one day (U of T student, February 2018).

3. I chose French because a cousin of mine got married to a French person and I wanted to be able to talk with him in French (Nagoya student, 2015).

The other seven students' accounts belong to the category of motivations that derive from an interest in mainstream French culture, including "the beautiful sound of French," famous historical buildings, and "non-Japonized, authentic French dishes":

4. I decided to enroll in this program because I long to speak French and look cool, and also because I like bike riding and want to be able to understand French commentators of Tour de France (Nagoya student, 2014). 
5. I chose French because of my akogare for France and the widespread use of French within the United Nations (U of T student, February 2017).

6. I chose French because I like French pastries. I am also charmed by the beautiful sound of French, and am interested in French history and culture (U of T student, February 2017).

7. I started to study French because I am a big fan of The Rose of Versailles [A once hugely popular girls' manga set in France featuring Marie Antoinette and others] (U of T student, February 2018).

8. I decided to enroll in this program because I was interested in visiting France, coming in contact with its culture, and using French (Nagoya student, 2014).

9. I enrolled in this program because I majored in architecture and became very interested in French architecture and streetscapes (Nagoya student, 2015).

10. I enrolled in this study program simply because I wanted to go to France for leisure and learn a lot of things that I can only learn by going there. More specifically, I wanted to feel what it was like to live in France by walking around the cities [Paris and Lyon], learn what French people my age are thinking by making friends with them, taste non-Japonized, authentic French dishes, and so on (U of T student, February 2019).

In both study abroad blog posts and post-study abroad writings, there was a limited amount of content on participants' motivations to study French in Japan or in France. This content was usually expressed through short sentences. Moreover, this topic was often mentioned in the context of other, more prominent topics, such as food and architecture, which most students highlighted in their writings together with pictures. As will be discussed later, this tendency is in line with institutional messages that devote considerable space to the significance of fun study abroad experiences, instead of the role of such experiences in contributing to the learning of the target language over a sustained period.

\section{Discussion}

Ideally, students' fond memories of a study abroad country would evolve into a long-term commitment to studying language and culture of the target country. However, this might be unlikely in many cases, as many students' sense of longing can be satisfied regardless of advanced-level French skills, and they often return home with the impression that their limited command of the target language did not negatively impact their joyful experiences, including socializing with locals. As we recall, a University of Tokyo student articulated that she "was able to fulfill" her initial goals of having a real sense of living in France and learning what French college students are thinking by the end of her ninth day in France.

Pointing out the dominance of students who take French as a non-major elective subject at an university in London, Oakes (2013) concludes that "If the future of language learning lies in non-specialist courses, as has been suggested, it is important that such students be as motivated as possible" (p. 189). That is a difficult directive, given that those nonspecialist students are apt to be content with short-term, fun learning experiences in local or study abroad contexts and discontinue their learning after completing courses taught at their home institutions or study abroad programs.

The role of higher education institutions and language teaching professionals in producing promotional materials and implementing fun-oriented, short-term study abroad programs 
must be considered when addressing college students' study abroad vacation expectations and attempting to raise their critical awareness. As shown in this study, programs and instructors of once well-respected European languages in Japan's higher education are compelled to reproduce romanticized and sanitized images and texts about their target languages and countries in order to attract the interest of college students. The situation at Japan's prestigious universities may suggest that amid increasing competition over foreign language learners, the survival of any foreign language program hinges on providing college students with an opportunity to engage in short-term, safe contact with the supposedly authentic culture of the host country. Textual and visual images of study abroad experiences that conflict with idealized images of a host country are commonly excluded from promotional materials and participants' testimonials. Thus, present-day college students' expectation to have fun-seeking study abroad experiences must be examined in the context of institutions of higher education and other social actors (e.g., the media and the business world) who are inadvertently or not complicit in maintaining the worldwide dominance of an ideology that equates short-term study abroad experiences with internationalization and global citizenship (Fairclough, 1993; Lewin-Jones, 2019; Michelson \& Valencia, 2016; Zhang \& O'Halloran, 2013).

Most importantly, certain languages can evoke a sense of longing and capitalize on romanticized images to maintain a competitive edge over departments that teach minor, less-popular languages. However, departments teaching competitive languages associated with a sense of longing for an idealized host country are disincentivized from exploring new approaches to promoting the language. Instead, such departments simply adhere to the dominant sentiment and images pervasive in mass media and the tourism industry. The popularity of these languages translates into the promotion of study abroad programs whose "website distances itself from typical practices in higher education, aligning itself instead with typical tourist industry practices" (Michelson \& Valencia, 2016: 251).

Meanwhile, the status of English as the world's global language has had a detrimental impact on the learning of other languages, in particular, students' commitment to longterm learning. The widespread use of English in Europe is a critical factor discouraging students to continue studying French. In contrast with Ishihara Satomi and many Japanese English learners who equate their encounters with English and an idealized Anglophone West with a sense of being international, students in French study abroad programs are not positioned to develop such feelings, as their daily use of English in France results in experiences that highlight the regional status of French vis-à-vis global English. The promotion of participation into French study abroad programs entails this risk of reminding the program participants of the widespread use of English in Europe.

Within this climate of global English dominance, some institutions of higher education (e.g., Faculty of Economics of a national university located in western Japan) choose to host study abroad programs at business schools in France that provide business English lessons and English-medium lectures on French culture, in addition to French language classes. The University of Tokyo's French study abroad program held in February 2018 also provided an opportunity for the students to attend English-medium lectures on the histories and cultures of English-speaking countries, together with local Universite libre de Bruxelles students. Those bilingual programs are feasible because English medium instruction is a burgeoning field in Europe, resulting from the worldwide competition for international students (Dimova et al., 2015; Reynolds, 2019). That said, it appears that French language programs in Japan have been discreet about bilingual programs that inadvertently highlight the spread of English in Europe and thus raise students' doubts about the significance of studying a Western language other than English. 
The popularity of European languages that were once highly respected in Japan, such as French, has been undermined by not only the dominance of English but also the rise of nonEuropean languages. For example, the number of Japanese universities offering French language classes has been declining steadily, from 543 in 2002 to 531 in 2008 and to 479 in 2016, whereas the number of universities offering Korean language classes continues to increase from 322 in 2002 to 429 in 2008 and to 469 in 2016, presumably due to the K-pop popularity in Japan (Monbukagakusho, 2021) (See also Kobayashi, 2013). Thus, French language courses and study abroad programs, which are reliant on Japanese college students' sense of longing for an idealized France, might be unsustainable in the future, as Japan's changing power relationship with the rest of Asia is likely to have an impact on Japan's longing for the West.

Finally, although it is beyond the scope of this study, it is worthwhile to note that there is a relatively balanced number of women and men participating in French study abroad programs. According to Carr and Pauwels (2006), Australian working-class male students associate French language with femininity, whereas their peers of higher socioeconomic status "have first-hand experience of overseas travel and intercultural contact" and "know from experience the benefits which accrue from other-language proficiency" (p. 94). A large percentage of students from prestigious universities (e.g., Harvard University) come from affluent households (Bolotnikova, 2017, January). Such students have enjoyed privileged access to overseas travel and intercultural experiences since childhood. Two University of Tokyo male students also had lived in France and Brussels, respectively. Such privileged exposure to Europe and other countries is likely to increase both female and male students' willingness to learn more about foreign countries. For reference, more than $70 \%$ of University of Tokyo students' families earn 7.5 million Japanese yen (68,000 USD) or more annually, thus placing them in a high socioeconomic bracket. More specifically, $13.5 \%$ of parents have an income of 68,000 to 86,000 USD, $21.3 \%$ with 86,000 to 95,000 USD, $11.2 \%$ with 95,000 to 113,000 USD, $12.2 \%$ with 113,000 to 140,000 USD, and $16.1 \%$ with more than 15.5 million JPY (140,000 USD) (The University of Tokyo, 2018: 41).

\section{Conclusion}

Students' decisions to study abroad and their expectations of the study abroad experience are intertwined with competition between language departments, the marketability of certain languages, study abroad ideologies, university-industry relationships, income inequality in higher education, and career planning for (un)privileged students. Although the Anglophone West is the most popular destination for international students, the study of college students' longing for non-Anglophone countries has the potential to broaden the perspectives of applied linguists and foreign language teaching professionals around the world. This is particularly relevant because the study abroad domain is predicated on the dominance of English, which is equated with internationalization and global citizenship. Moreover, given that the COVID-19 pandemic has profoundly disrupted international student mobility across the globe, future studies should examine how societal, institutional, individual, and ideological factors may alter college students' desires and motivations to study abroad. In particular, scholars should study the impact of the pandemic on students' pre-pandemic fun-oriented expectations regarding encounters with idealized foreign countries, whether the locally dominant language is an iconic world language, a regional but historically romanticized language, or a newly emerging non-Western language associated with pop culture. 


\section{Declarations}

I state here that no interests are directly or indirectly related to this manuscript submitted for publication, including financial interests, professional ones, personal relationships, or personal beliefs that could impart bias on the work. Moreover, no research grants from funding agencies are used for this research, and thus no funding information is needed for this submission. This work based on content discourse analysis does not involve an experiment with humans and/animals, and thus the issue of informed consent is not required.

\section{References}

Bolotnikova, M. N. (2017). Harvard's economic diversity problem. Harvard Magazine.

Carr, J., \& Pauwels, A. (2006). Boys and foreign language learning: Real boys don't do languages. Palgrave. Chilton, M. (2016). English studies beyond the 'center': Teaching literature and the future of global English. Routledge.

College of Arts and Sciences of the University of Tokyo. (2019). Kokusai kenshu 'TLP French summer program' no tanoshimi [The fun part of an overseas program, TLP French summer program]. Kyouyougakubuhou [College of Arts and Sciences Bulletin], 613. https://www.c.u-tokyo.ac.jp/info/about/bookl et-gazette/bulletin/613/open/613-03-1.html

Dimova, S., Hultgren, A. K., \& Jensen, C. (2015). English-medium instruction in European higher education: English in Europe. Mouton De Gruyter.

Doyon, P. (2001). A review of higher education reform in modern Japan. Higher Education, 41(4), 443-470.

Fairclough, N. (1993). Critical discourse analysis and the marketization of public discourse: The universities. Discourse and Society, 4(2), 133-168.

Fairclough, N. (2013). Critical discourse analysis: The critical study of language. Routledge.

Fan, Y. (2019). How were foreign language courses excluded from general education curriculum in post-war reforms: A study on the transition of the discourses inside JUAA [text in Japanese]. Daigaku Ronshu [Hiroshima University], 51. https://doi.org/10.15027/47525

Gottlieb, N. (2012). Language policy in Japan: The challenge of change. Cambridge University Press.

Ishimaru, K. (2009). Stereotypes reciproques en France et au Japon : Resultats d'une enquete aupres d'etudiants francais et japonais [A study on mutual stereotypes between Japan and France: Results from a questionnaire survey of Japanese and French students] [text in Japanese]. Revue Japonaise de Didactique du Français, 4. https://doi.org/10.24495/rjdf.4.2_133

JICA Research Institute. (2004). The history of Japan's educational development: What implications can be drawn for developing countries today. https://www.jica.go.jp/jica-ri/IFIC_and_JBICI-Studies/english/ publications/reports/study/topical/educational/index.html

Kinginger, C. (2004). Alice doesn't live here anymore: Foreign language learning and identity reconstruction. In A. Pavlenko \& A. Blackledge (Eds.), Negotiation of Identities in Multilingual Contexts (pp. 219-242). Multilingual Matters Ltd.

Kinginger, C. (2009). Language learning and study abroad: A critical reading of research. Palgrave MacMillan.

Kobayashi, Y. (2013). Europe vs. Asia: Foreign language education other than English in Japan's higher education. Higher Education, 66(3), 269-281.

Kobayashi, Y. (2018). The neo-liberal notion of global language skills vs. monolingual corporate culture: Co-existence or rivalry? Journal of Multilingual and Multicultural Development, 39(8), 729-739.

Kobayashi, Y. (2021). Non-globalized ties between Japanese higher education and industry: Crafting publicity-driven calls for domestic and foreign students with global qualities. Higher Education, 81(2), 241-253.

Kress, G., \& van Leeuwen, T. (1996). Reading images: The grammar of visual design. Routledge.

Krippendorff, K. (2004). Content analysis: An introduction to its methodology. Sage.

Lewin-Jones, J. (2019). Discourses of 'internationalisation': A multimodal critical discourse analysis of university marketing webpages. Research in Post-Compulsory Education, 24(2-3), 208-230.

Michelson, K., \& Valencia, J. A. Á. (2016). Study abroad: Tourism or education? A multimodal social semiotic analysis of institutional discourses of a promotional website. Discourse \& Communication, 10(3), $235-256$.

Mogi, R. (2016). Tanki ryugaku niyoru furansugo gakushu taido no henyo [The impact of a short-term study abroad experience on attitudes toward French study]. Journal of the Nanzan Academic Society (Nanzan University): Literature and Language, 99. https://doi.org/10.15119/00000721 
Monbukagakusho. (1990). White Paper: Japanese Government Policies in Education, Science and Culture 1990. https://www.mext.go.jp/b_menu/hakusho/html/monbu.htm

Monbukagakusho. (1996). White Paper: Japanese Government Policies in Education, Science and Culture 1995. https://www.mext.go.jp/b_menu/hakusho/html/monbu.htm

Monbukagakusho. (2021). Daigaku niokeru kyoiku naiyo tono kaikakujokyo nitsuite [The status of educational reforms in higher education]. Available at: https://www.mext.go.jp/a_menu/koutou/daigaku/ 04052801/005.htm. Accessed 6 Nov 2021.

Monbusho. (1980). Japan's modern educational system: A history of the first hundred years. https://www. mext.go.jp/b_menu/hakusho/html/others/detail/1317220.htm

Nagatomo, D. H. (2012). Exploring Japanese University English Teachers' Professional Identity. Multilingual Matters.

Nonaka, C. (2018). Transcending self and other through Akogare [Desire]: The English language and the internationalization of higher education in Japan. Multilingual Matters.

Oakes, L. (2013). Foreign language learning in a 'monoglot culture': Motivational variables amongst students of French and Spanish at an English university. System, 41(1), 178-191.

Oricon Inc. (2018). Celebrities you'd want to be your English teacher: Ishihara Satomi ranked first, Pakkun second [text in Japanese]. English Style. https://juken.oricon.co.jp/rank_english/special/entertainment/ 20180323/

Patton, M. Q. (2002). Qualitative, research \& evaluation methods. Sage.

Reynolds, A. (2019). Constructing lecturers' language identities through EMI training. Researching and Teaching Languages for Specific Purposes, 38. https://doi.org/10.4000/apliut.7210

Tajima, H. (2002). L'évolution de l'enseignement du français au Japon après la 2e Guerre mondiale [French language education in Japan: A reflection on its post-war 50-year history] [text in Japanese]. La Societe Japonaise de Didactique du Francais, 30. https://doi.org/10.24495/efj.30.0_15

The University of Tokyo. (2018). Dai 85 kai gakusei seikatsu jittai chosa hokokusho [The 68th student life survey report]. https://www.u-tokyo.ac.jp/ja/students/edu-data/h05.html

van Dijk, T. A. (1993). Principles of critical discourse analysis. Discourse \& Society, 4(2), 249-283.

Zhang, Y., \& O'Halloran, K. L. (2013). 'Toward a global knowledge enterprise': University websites as portals to the ongoing marketization of higher education. Critical Discourse Studies, 10(4), 1-18.

Publisher's note Springer Nature remains neutral with regard to jurisdictional claims in published maps and institutional affiliations. 